$\begin{array}{ll}\begin{array}{ll}\text { Australian Journal of } \\ \text { Crop Science }\end{array} & \text { A T CS } \\ \text { AJCS 15(07):1013-1019(2021) } & \text { ISSN:1835-2707 }\end{array}$

AJCS 15(07):1013-1019 (2021)

ISSN:1835-2707

doi: 10.21475/ajcs.21.15.07.p3022

\title{
Processing of fermented milk drink with different whey concentrations and addition of fruit pulps
}

\author{
Nélio Ranieli Ferreira de Paula ${ }^{1}$, Érica de Oliveira Araújo ${ }^{1}$, Cristiane Reis Martins $^{2}$, Vanessa Reis \\ Martins $^{3}$
}

${ }^{1}$ Agronomy, Department of Agriculture, Federal Institute of Education, Science and Technology, Rondonia State, Campus Colorado do Oeste, Brazil

${ }^{2}$ Agronomic Engineering, Department of Agronomy, Federal Institute of Education, Science and Technology, Rondonia State, Campus Colorado do Oeste, Brazil

${ }^{3}$ Technical in Agriculture, Department of Agriculture, Federal Institute of Education, Science and Technology, Rondonia State, Campus Colorado do Oeste, Brazil

*Corresponding author: erica.araujo@ifro.edu.br

\begin{abstract}
Using whey as a complement in food formulation aiming at its utilization is an alternative to obtain new products. The present study aimed to develop a fermented milk drink with different concentrations of whey and addition of cupuaçu, soursop and açaí pulps, aiming at innovating and increasing the possibilities of production and consumption of dairy beverages. The experiment was conducted at the Food Agroindustry of the Federal Institute of Education, Science and Technology of Rondonia, Colorado do Oeste Campus, in the municipality of Colorado do Oeste, RO, Brazil. The experimental design used was completely randomized, in a $3 \times 3$ factorial scheme, consisting of three concentrations of whey $(30 \%, 40 \%$ and $50 \%$ ) and the incorporation of three fruit pulps (cupuaçu (Theobroma grandiflorum), soursop (Annona muricata) and açaí (Euterpe oleracea)), with 4 replicates. The results allowed us to conclude that whey concentration of $50 \%$ with addition of cupuaçu, soursop and açaí pulps is ideal for the production of fermented milk drink, as it leads to increased acidity and reduced values of ${ }^{\circ}$ Brix and color parameters $L$ and $b^{*}$, making it possible to avoid the disposal of a highly nutritious compound into the environment. Whey concentration of $30 \%$ in the presence of açaí pulp enables the processing of milk drink with lower value of acidity and higher values of ${ }^{\circ} B$ rix and color parameters $L$ and $b^{*}$. Whey concentrations of $30 \%$ and $40 \%$ in the fermented milk drinks of cupuaçu, soursop and açai reduced acidity and increased ${ }^{\circ}$ Brix, which suggests the possibility of using this by-product in the food industry to prepare sweeter milk drinks, meeting the minimum quality requirements according to the current legislation. The processing of whey-based dairy drinks in the presence of pulps of fruits, such as cupuaçu, soursop and açaí, constitutes an opportunity for diversification of production, improvement in the development of regional products and guarantee of food and nutritional security, respecting microbiological quality standards.
\end{abstract}

Keywords: Fermentation. Whey. Theobroma grandiflorum. Annona muricata. Euterpe oleracea. Value addition.

\section{Introduction}

In 2019, Brazil produced 58.37 billion liters of cow's milk, collected at the national level and from dairy industries from the different units of the Federation (Ibge, 2020). Currently, Rondonia is the seventh largest milk producer in Brazil, with production of 670.4 million liters in 2019 , being a reference in the Northern Region.

Milk drink is understood as the milk product resulting from the mixture of milk and whey, with or without food products or substances, vegetable fat and other dairy products, in which the milk base represents at least $51 \%$ of all ingredients. Fermented milk drink, in turn, receives the addition of specific microorganisms and cannot be subjected to heat treatment after the fermentation process, so that the total count of viable lactic bacteria is at least $10^{6} \mathrm{CFU} / \mathrm{g}$ in the final product along the entire shelf life (Brasil, 2005). Whey, technically called milk serum, is a by-product resulting from either cheese making or casein extraction. This by-product retains about $55 \%$ of milk nutrients and is considered relevant given the volume produced and its nutritional composition (Leite et al., 2012).

It is estimated that, on average, ten liters of milk are needed to make one kilo of cheese, with production of nine liters of whey (Barbosa et al., 2010). Thus, the generation of whey from cheeses produced in Brazil is relevant, with estimates of a value close to 6.03 million tons. For this reason, there is a recurrent concern to find applicability for cheese whey in new foods because in the Brazilian territory approximately $50 \%$ of the whey is not utilized, which generates nutritional waste, financial losses and significant environmental impacts, as small industries and small producers face difficulties with the excess whey and mostly choose to dispose of the product directly in the public network and in rivers and lakes, causing daily pollution of organic material equivalent to that of about 470 people for each ton of untreated whey that is disposed of (Andrade; Martins, 2002).

In this perspective, the production of milk drink in Brazil has become one of the main options for making use of whey at 
low cost and with ease of processing, employing equipment already existing in the industry (Pintado et al., 2001). The possibility of mixing cheese whey with fruits to obtain beverages, dairy products, soups and desserts would have as a benefit a product consisting of fibers, vitamins and minerals, which is an alternative in the composition of diets for specific institutional groups, besides meeting the market demand for a greater variety of products of this nature (Guedes et al., 2013). In addition, together with the nutritional characteristics of whey, the demand of the Brazilian consumer for healthier, innovative, safe and practical products has contributed to the increase in milk drink production (Santos; Ferreira, 2001). However, the possibility of adding pulps of fruits, such as açaí, cupuaçu and soursop, among others, to dairy drinks has already taken a prominent place at the consumer's table, both nationally and internationally.

Among the main interests in the use of fruits to improve the acceptance of dairy beverages are those related to the marketing strategies focused on these products, whose goal is to offer new food options to consumers (Siqueira et al., 2013) and, among the fruits of the Amazon with economic potential, the following ones stand out: cupuaçu (Theobroma grandiflorum), mainly because of its characteristics of flavor, aroma and possibilities of domestic and agroindustrial utilization of its pulp; soursop (Annona muricata L.), considered a good natural source of antioxidants (Baskar et al., 2007), composed of B-complex vitamins, flavonoids and minerals; and açaí (Euterpe oleracea), which has a high nutritional and sensory value, being even considered a functional food due to its high content of anthocyanins, besides being rich in proteins, fibers, lipids and mineral salts, and a natural antioxidant that acts in the elimination of free radicals.

Therefore, in view of the above, the present study aimed to develop a fermented milk drink with different concentrations of whey and addition of cupuaçu, soursop and açaí pulps, aiming at innovating and increasing the possibilities of production and consumption of dairy beverages.

\section{Results and discussion}

Regarding the physicochemical characteristics, the results showed significant effects $(p \leq 0.05)$ of the interaction between whey concentrations and fruit pulps for the color parameters $\mathrm{L}$, $\mathrm{a}^{*}$ and $\mathrm{b}^{*}$, acidity and ${ }^{\circ}$ Brix (Table 1 ), while the independent effects for each factor are presented in Figure 1 and Figure 2.

\section{Physicalchemical analysis}

For chemical analyses of $\mathrm{pH}$, the treatment with whey and addition of açaí pulp showed a significant difference $(p<0.05)$ in comparison to the others, whose $\mathrm{pH}$ values were on the order of 4.5, corroborating the lower titratable acidity compared to the pulps of cupuaçu and soursop and, in contrast, higher value of ${ }^{\circ}$ Brix (Figure $1 \mathrm{~A}$ ). This may be indicative of quality in the processing of milk drink containing açaí, since the $\mathrm{pH}$ value is within the recommended range for the development of milk drink. On the other hand, whey with addition of cupuaçu pulp showed more acidic $\mathrm{pH}$, higher titratable acidity and lower value of ${ }^{\circ}$ Brix, not differing statistically in some parameters from the treatment with soursop pulp (Figure 1A).

Acidity has great influence on the quality attributes of dairy products and is one of the factors that limit their acceptance. The moderate acidity of dairy beverages favors their acceptability by consumers, besides being important in the visual aspect of the final product during storage under refrigeration. The results of $\mathrm{pH}$ and titratable acidity are similar to those reported by Oliveira et al. (2006), who obtained results between 4.1 and 4.2 and concluded that these values do not mischaracterize the product as they are similar to those of milk drink, which is on average 4.5. According to Kandler and Weiss (1986), the species Lactobacillus spp. are considered aciduric, since they usually grow at $\mathrm{pH}$ between 5.5 and 6.2; however, they can also grow at $\mathrm{pH}$ below 5.0, as found in fruits of the Western Amazon, such as cupuaçu and açaí. In this context, it is accepted that optimal conditions for growth of lactic bacteria occur within a specific $\mathrm{pH}$ range, depending on the bacterial species.

In addition, Antunes (2003) showed that there are two types of whey to be used by the food industry: acid $(\mathrm{pH}<5.1)$ and sweet $(\mathrm{pH}>5.6)$. Acid whey is the by-product of the manufacture of food casein or fresh cheese, resulting from acidification of milk with direct addition of acid and glucono delta-lactone or by in-situ production of acid by lactic fermentation, respectively.

Thus, it is possible to infer that the higher the concentration of whey in the composition, the higher the values of titratable acidity and the lower the values of ${ }^{\circ} \mathrm{Brix}$, and that the opposite is true for the whey concentrations of $30 \%$ and $40 \%$ (Figure $2 \mathrm{~B})$, so the product is according to the Technical Regulation of Identity and Quality, which establishes minimum acidity of $2.50 \%$ of citric acid and at least $11^{\circ}$ Brix (Brasil, 2000). The oBrix scale is calibrated by the number of grams of sugar contained in $100 \mathrm{~g}$ of solution. When measuring the refractive index of a sugar solution, the reading in percentage of ${ }^{\circ} \mathrm{Brix}$ should match the actual concentration of sugar in the solution. The scales in percentage of ${ }^{\circ}$ Brix present the percentage concentrations of soluble solids contained in a sample (solution with water). The soluble solids contained are the total of all solids dissolved in water, starting with sugar, minerals, proteins, organic acids etc. It should be pointed out that, as the fruit develops, sugar accumulates in the pulp until it reaches the appropriate level for harvesting. The ideal content for the fruit to be considered of good quality, in some cases, will depend on the destination of the fruit for processing. In this context, Macêdo et al. (2011) performed physicochemical evaluation of fermented dairy drink with addition of passion fruit pulp and obtained $15 \%$ of ${ }^{\circ}$ Brix in the final product. Similarly, in the present study medium values of total soluble solids were observed only for the lower concentrations of whey (30\% and $40 \%)$, but for the concentration of $50 \%$ there was a reduction in the contents of total soluble solids, which differed statistically $(p<0.05)$, as verified in Figure $1 \mathrm{~B}$ and in the decomposition of the interactions between whey concentration and fruit pulp (Table 1).

As for the variables $L$ and $b^{*}$, the treatment with $30 \%$ whey showed significantly higher values than the others (Figure $2 \mathrm{~A})$, i.e., it enabled the processing of milk drink with greater lightness and, therefore, higher values of oBrix and lower values of acidity (Figure $1 \mathrm{~B}$ ) compared to the other whey concentrations, which may be interesting for the production of sweeter dairy beverages, because many consumers choose drinks that are lighter and with no possibility of oxidation. The $\mathrm{L}$ parameter indicates lightness and can assume values between zero (0) and one hundred (100), being called black and white, respectively. As the whey concentration in the milk drink increased, the value of $L$ decreased. Lower values of $L$ were found in treatments with $50 \%$ whey, but this reduction was statistically significant with the addition of açaí pulp, 
which may have evidenced greater homogenization and balance in the contents of the constituents of the fruit pulps (cupuaçu, soursop and açaí) for \% juice, fiber, fat and protein, favoring the reduction of free water due to the increase in total solids and resulting in lower light reflection (GarcíaPérez et al., 2005).

Milk drink with whey concentration of $50 \%$ showed good lightness, yellowish color and moderate acidity, differing statistically $(p<0.05)$ from the other treatments with addition of $30 \%$ and $40 \%$ of whey (Figure $2 \mathrm{~A}$ ). It was observed that the values obtained for $a^{*}$ (intensity of red/green) are closer to red for the blend with addition of açaí pulp, while the values of $L$ and $b^{*}$ (intensity of yellow/blue) pointed to intensity tending to yellow, as verified for the blends with addition of cupuaçu pulp (Figure 2B), which demonstrates an inverse relationship regarding the addition and mixture of different concentrations of açaí and cupuaçu. Thus, the higher the values $\mathrm{a}^{*}$, the lower the lightness ( $\mathrm{L}$ ) of the blends formulated with açaí; consequently, the lower the values a*, the higher the lightness $(L)$ of the blends formulated with cupuaçu and soursop. However, this conclusion is variable according to the species to be used.

\section{Unfolding of the double interaction}

The decomposition of the double interaction between whey concentration and fruit pulp showed that whey concentration of $50 \%$ with addition of cupuaçu, soursop and açaí pulps was superior in terms of acidity, i.e., higher values of acidity and lower values of ${ }^{\circ}$ Brix, differing statistically from the concentrations of $30 \%$ and $40 \%$ (Table 1). However, when the whey concentration in the drink increases, there is a reduction in the values of ${ }^{\circ} \mathrm{Brix}$ and in the soluble solids present in the final product, which characterizes a less sweet taste. Whey concentration of $30 \%$ in the presence of açai pulp promoted the lowest value of acidity among the fruit pulps analyzed and the highest values of ${ }^{\circ} \mathrm{Brix}$, while the cupuaçu pulp at all whey concentrations showed high acidity (Table 1), which corroborates the individual results, due to low $\mathrm{pH}$ (3.9) and high natural acidity of cupuaçu pulp (Figure $2 \mathrm{~A}$ ). Paula et al. (2020) found that presence of cupuaçu pulp in fermented milk contributes to reducing $\mathrm{pH}$ values and increasing acidity, lightness, $b^{*}$ and \%Brix, corroborating the results found in the present study, in which the fermented milk drink with $50 \%$ whey showed a significant decrease of oBrix when cupuaçu, soursop and açaí pulps were added (Table 1 ).

The color parameters $L$ and $b^{*}$ at the different concentrations of whey, $30 \%, 40 \%$ and $50 \%$ respectively, were higher when cupuaçu pulp was added, while a* had the lowest values, not differing statistically from each other at the different concentrations of whey (Table 1), which may be slightly related to the color of fruit, whey and milk. For the addition of açaí pulp, the color parameters $\mathrm{L}$ and $\mathrm{b}^{*}$ were higher at whey concentration of $30 \%$ than at concentrations of $40 \%$ and $50 \%$, which differed statistically from each other, while a* was negative. The opposite occurred for the milk drink with whey concentration of $50 \%$, in which $L$ and $b^{*}$ were lower than in the drink with whey concentrations $30 \%$ and $40 \%$ and a* showed higher and positive values, differing statistically from each other (Table 1). It is evident with the results that the use of whey at the maximum concentration of $50 \%$ by the food industry, besides avoiding the disposal of a highly nutritious compound into the environment, reduces the costs with waste treatment, contributing to the development of new products aiming to meet the expectation of regional, national and international consumers who seek products with high protein content and sensory and nutritional quality.

\section{Sensory analysis}

According to the technical regulations of identity and quality of milk drink (Brasil, 2005), the current legislation does not establish the value of acidity for milk drinks, pasteurized or not, so there is not a parameter to be followed in legislation. In this context, sensory tests aim to measure the subjective attitude of the consumer regarding the acceptance or preference of products, because determining acceptance by the consumer is a crucial part in the development and improvement of a product. Milk drinks with whey concentration of $50 \%$ and addition of the different fruit pulps were subjected to sensory analysis to evaluate consumer acceptance. For this, attributes of color, texture, flavor, consistency, aroma and overall aspect were evaluated using a 9-point scale, which contain the defined terms situated between "liked extremely" and "disliked extremely". The intent with the formulations was to employ the maximum concentration of whey (50\%) in order to increase the possibility of its utilization and prepare drinks with the pleasant flavor of the fruit, regardless of the consistency obtained, and with imperceptible taste of whey, as its mineral-rich composition is not pleasant to the taste (Siqueira et al., 2002).

For the sensory attributes of color and aroma, the treatments with whey and addition of cupuaçu and açaí pulps did not differ statistically from each other $(p<0.05)$ and were significantly superior to the treatment with whey and addition of soursop pulp, whose values were within the class of "liked moderately" (Table 2). In these attributes, the milk drinks with cupuaçu and açaí flavors showed average increments of acceptance on the order of $22 \%$ and $10 \%$ for color and aroma, respectively, compared to the drink containing soursop, which indicates a product of good acceptance and with the possibility of commercialization.

For the texture and consistency attribute, opposite results were observed, in which the treatment with addition of açai pulp had the lowest values. This can be attributed to the type of fruit pulp used for production, as a reasonable water content was found, which may have enabled the change in texture and quality of the milk drink; whereas the milk drinks containing cupuaçu and soursop showed similar values and did not differ statistically for the texture and consistency attribute (Table 2).

The flavor and overall aspect of the milk drink with addition of cupuaçu pulp differed statistically from the others and was higher, with average increments of $12 \%$ and $8.67 \%$ compared to treatments with açaí pulp and soursop pulp (Table 2). It can be inferred that these results are closely linked to the fact that the regional flavors used are still uncommon to the taste of the evaluators, but the means of the evaluations remain as moderate to good according to the data presented (Figure 2). For the milk drink of soursop, the acceptance was low compared to the others, which may be correlated with the difficulty in identifying the flavor of soursop fruit in the beverage, as it is little noticeable, with flavor close to the natural flavor of the milk drink, contributing to its low evaluation, corroborating the results found for color and aroma (Table 2).

Menezes (2011), when developing a fermented milk drink based on whey and cajá (Spondias mombin) pulp, observed that the formulations with $20 \%, 30 \%$ and $40 \%$ of whey in partial replacement to milk, totaling a milk base that ranged from $75 \%$ to $85 \%$, showed satisfactory results, obtaining an 
Table 1. Unfolding of the double interaction between lacteo serum concentrations and addition of different fruit pulps.

\begin{tabular}{|c|c|c|c|}
\hline \multirow[t]{2}{*}{ Lacteo serum concentrations } & \multicolumn{3}{|l|}{ Acidity } \\
\hline & Cupuaçu & Soursop & Açaí \\
\hline $30 \%$ & $98.00 \mathrm{cA}$ & $58.00 \mathrm{bB}$ & $39.33 \mathrm{bC}$ \\
\hline $40 \%$ & 64.66 bA & $56.66 \mathrm{bB}$ & $44.66 \mathrm{bC}$ \\
\hline $50 \%$ & $106.00 \mathrm{aA}$ & $66.66 \mathrm{aC}$ & $74.66 \mathrm{aB}$ \\
\hline \multirow[t]{2}{*}{ Lacteo serum concentrations } & \multicolumn{3}{|l|}{${ }^{\circ}$ Brix } \\
\hline & Cupuaçu & Soursop & Açaí \\
\hline $30 \%$ & $19.83 \mathrm{bB}$ & $18.83 \mathrm{bB}$ & $25.50 \mathrm{aA}$ \\
\hline $40 \%$ & $25.40 \mathrm{aA}$ & $24.20 \mathrm{aA}$ & $20.16 \mathrm{bA}$ \\
\hline $50 \%$ & $12.20 \mathrm{cA}$ & $12.16 \mathrm{cA}$ & $11.86 \mathrm{cB}$ \\
\hline \multirow[t]{2}{*}{ Lacteo serum concentrations } & \multicolumn{3}{|c|}{ Colorimetric L } \\
\hline & Cupuaçu & Soursop & Açaí \\
\hline $30 \%$ & $77.46 \mathrm{aA}$ & $75.30 \mathrm{bB}$ & $75.76 \mathrm{aB}$ \\
\hline $40 \%$ & $77.76 \mathrm{aA}$ & $76.46 \mathrm{aB}$ & $41.73 \mathrm{bc}$ \\
\hline $50 \%$ & $76.86 \mathrm{aA}$ & $71.00 \mathrm{cB}$ & $28.40 \mathrm{cC}$ \\
\hline \multirow[t]{2}{*}{ Lacteo serum concentrations } & \multicolumn{3}{|c|}{ Colorimetric a* } \\
\hline & Cupuaçu & Soursop & Açaí \\
\hline $30 \%$ & $-0.46 \mathrm{aA}$ & $-0.50 \mathrm{bA}$ & $-0.50 \mathrm{cA}$ \\
\hline $40 \%$ & $-0.43 a B$ & $-0.40 \mathrm{bB}$ & $10.50 \mathrm{bA}$ \\
\hline $50 \%$ & $-0.50 a B$ & $-0.96 c C$ & $13.33 \mathrm{aA}$ \\
\hline \multirow[t]{2}{*}{ Lacteo serum concentrations } & \multicolumn{3}{|c|}{ Colorimetric b* } \\
\hline & Cupuaçu & Soursop & Açaí \\
\hline $30 \%$ & $9.76 \mathrm{abB}$ & $8.70 \mathrm{aB}$ & $10.00 \mathrm{aA}$ \\
\hline $40 \%$ & $10.00 \mathrm{aA}$ & $7.96 \mathrm{aB}$ & 7.46 bB \\
\hline $50 \%$ & $9.46 \mathrm{abA}$ & $4.76 \mathrm{bC}$ & $5.56 \mathrm{cB}$ \\
\hline
\end{tabular}
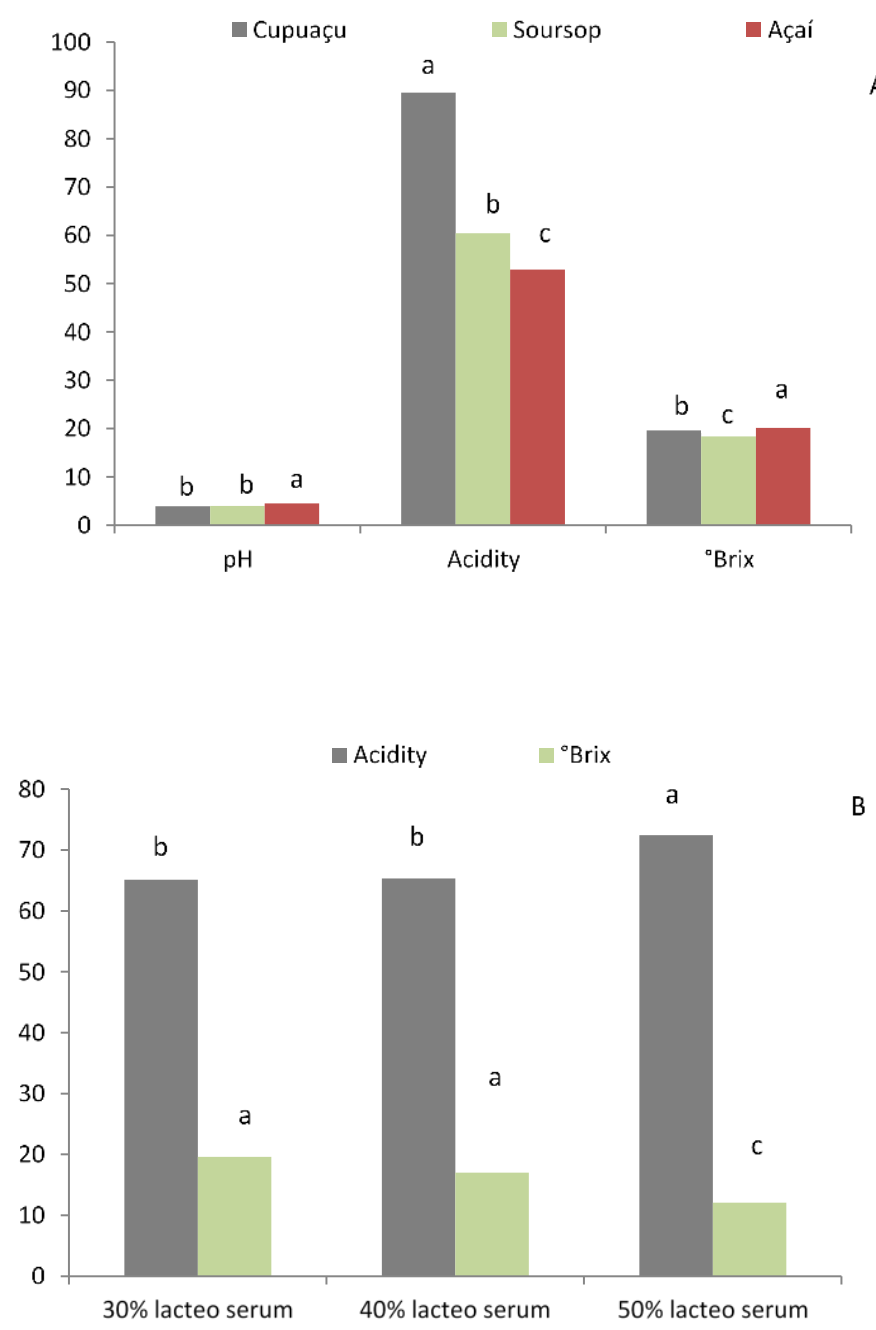

Figure 1. Values of $\mathrm{pH}$, acidity and ${ }^{\circ} \mathrm{Brix}$ for milk drink added of different fruit pulp (A) and values of acidity and ${ }^{\circ} \mathrm{Brix}$ for milk drink based on different concentrations of lacteo serum (B). Means followed by the same letter in the column do not differ statistically by Tukey test at $5 \%$ probability. 
Table 2. Sensory analysis of fermented dairy beverage in the concentration of $50 \%$ of added lácteo serum of cupuaçu pulp, soursop and açaí.

\begin{tabular}{|l|l|l|l|l|l|l|}
\hline Tratamento & Color & Texture & Consistency & Aroma & Flavor & Aspect \\
\hline Serum + cupuaçu & $7.39 \mathrm{a}$ & $7.36 \mathrm{a}$ & $6.21 \mathrm{a}$ & $7.18 \mathrm{a}$ & $7.75 \mathrm{a}$ & $7.55 \mathrm{a}$ \\
\hline Serum + soursop & $6.07 \mathrm{~b}$ & $7.01 \mathrm{a}$ & $6.72 \mathrm{a}$ & $6.33 \mathrm{~b}$ & $6.50 \mathrm{c}$ & $6.75 \mathrm{c}$ \\
\hline Serum + açaí & $7.47 \mathrm{a}$ & $6.28 \mathrm{c}$ & $5.88 \mathrm{c}$ & $7.15 \mathrm{a}$ & $7.19 \mathrm{~b}$ & $7.15 \mathrm{~b}$ \\
\hline
\end{tabular}

Means followed by the same letter in the columns do not differ from each other by the Tukey test at the $5 \%$ probability level. $n=80$ judges. Structured hedonic scale of nine points $(1=$ disliked very much; $9=$ liked it very much).

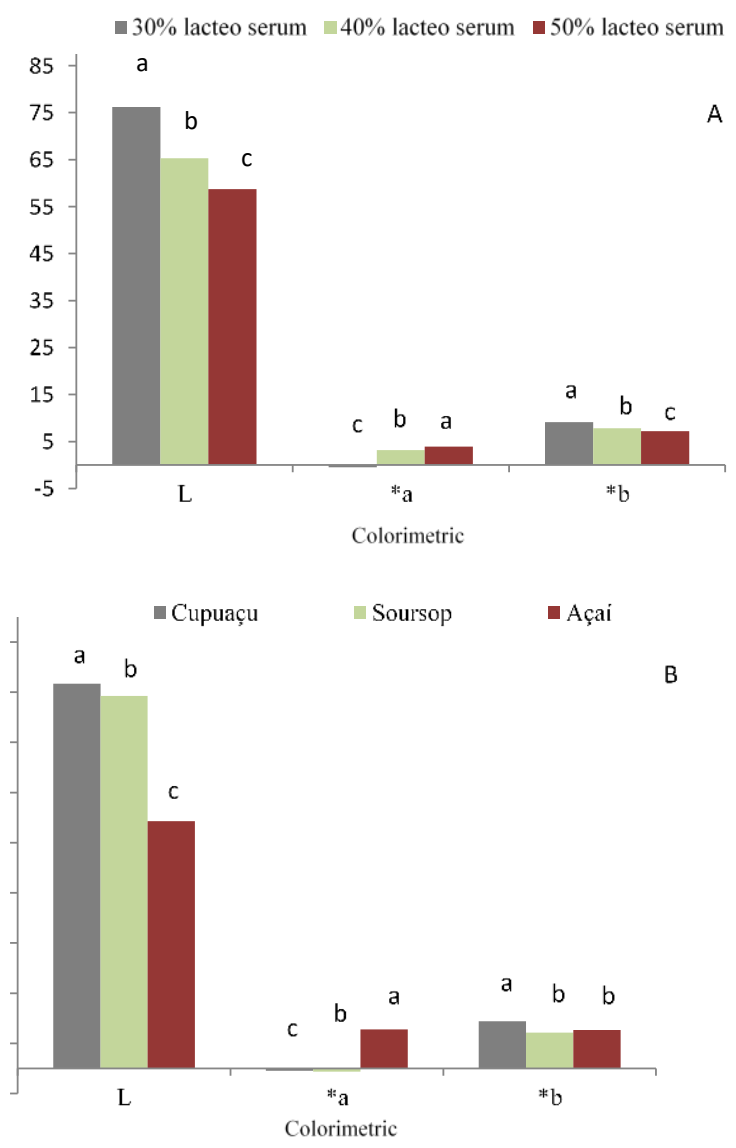

Figure 2. Colorimetric $L$, colorimetric $a^{*}$ and colorimetric $b^{*}$ for milk drink based on different concentrations of lateo serum (A), and milk drink added from different fruit pulp (B). Means followed by the same letter in the column do not differ statistically by Tukey test at $5 \%$ probability.

Table 3. Microbiological analysis of dairy beverages based on whey and fruit pulp.

\begin{tabular}{|l|l|}
\hline Analysis & Results \\
\hline Total Bacterial Count & $<20 \mathrm{UFC} / \mathrm{mL}$ \\
\hline Psychotrophic Aerobic Microorganisms & Negative \\
\hline Escherichia Coli & Negative \\
\hline Enterobactérias & Negative \\
\hline Estafilococos aureus & Negative \\
\hline *Colony Forming Units. & \\
\hline
\end{tabular}

acceptability index greater than $70 \%$, a result also found in this study. Santos et al. (2006) developed a fermented milk drink containing mozzarella cheese whey $(20 \%, 40 \%, 60 \%$ and $80 \%$ ), with addition of umbu (Spondias tuberosa) pulp, and the physicochemical characteristics and sensory acceptance showed no significant difference for the studied formulations with whey, and these authors also found that the drink with $60 \%$ of whey was more viable in terms of utilizing the largest volume of by-product. Similarly, Paula et al. (2020) developed fermented milks with addition of different blends of Amazonian fruits and found that the concentrations of $100 \%$ cupuaçu, $70 \%$ cupuaçu $+30 \%$ cocoa and $60 \%$ cupuaçu $+40 \%$ cocoa promoted greater acceptability regarding color and texture, while the aroma and flavor variable in fermented milk with addition of $70 \%$ cupuaçu $+30 \%$ cocoa led to the highest values of acceptability.

\section{Microbiological analyses}

Microbiological analyses were performed by plating and rapid tests, which showed negative results for Escherichia coli, Enterobacteria and Staphylococci aureus, as presented in Table 3, and $18 \mathrm{CFU}$, which is below the value specified by legislation for dairy products, thus evidencing the quality in 
the preparation of milk drinks and ensuring the quality of the final product for the consumer.

Using whey to produce milk drink is an excellent alternative for the proper disposal of this effluent from cheese production, which can pose serious risks to the environment when not treated. The use of regional flavors adds value to the final product, besides bringing greater visibility to the exploitation of traditional fruits in the region. Microbiological and physicochemical analyses indicated a product with good quality and without the presence of contaminating microorganisms, ensuring safety of the final consumer. Through sensory analysis it was possible to identify the main aspects that need to be improved in the flavors of cupuaçu, soursop and açaí, such as consistency and aroma, and to note that, for the soursop pulp, the consumer has difficulty identifying the characteristic flavor of the fruit, because it was close to the natural flavor of the unflavored milk drink.

\section{Materials and methods}

\section{Study of site}

The experiment was conducted at the Food Agroindustry of the Federal Institute of Education, Science and Technology of Rondonia, Colorado do Oeste Campus, in the municipality of Colorado do Oeste, RO, Brazil, whose geographic coordinates are $13^{\circ} 06^{\prime} \mathrm{S}$ and $60^{\circ} 29^{\prime} \mathrm{W}$, with an average altitude of 407 meters.

\section{Experimental design}

The experimental design used was completely randomized, in a $3 \times 3$ factorial scheme, consisting of three concentrations of whey $(30 \%, 40 \%$ and $50 \%)$ and the incorporation of cupuaçu (Theobroma grandiflorum), soursop (Annona muricata) and açaí (Euterpe oleracea) pulps, with four replicates, totaling 36 experimental units.

\section{Conduction of the study}

The milk used to conduct the test was produced in the Animal Science sector of the Federal Institute of Education, Science and Technology of Rondonia, Colorado do Oeste Campus, and supplied to the Food Agroindustry, after the first milking of the morning. The test was conducted using $25 \mathrm{~L}$ of milk collected in 50-L gallons previously sanitized and sterilized, with subsequent pasteurization at 65 o $\mathrm{C}$ for 30 minutes. The fresh whey used $(25 \mathrm{~L})$ was collected in the morning after cheese production, using 50-L gallons for transport and filtration, and then subjected to analysis of acidity and $\mathrm{pH}$. The cupuaçu, soursop and açaí pulps were purchased at local markets, in the form of frozen pulp, separated into $100 \mathrm{~g}$ samples and placed in isothermal boxes containing Gelox to preserve the temperature and quality of the product at the time of collection. At the agroindustry, they were immediately washed and sanitized using $5 \mathrm{~mL}$ of hypochlorite per liter of water.

The milk drinks were prepared using $25 \mathrm{~L}$ of pasteurized milk and $25 \mathrm{~L}$ of cheese whey in the proportion of $50 \%$ for each constituent, with addition of Docina milk culture containing the microorganisms Lactobacillus delbruechii sub sp. bulgaricus and Streptococis salivarius sub sp. thermophilus, $12 \%$ sugar, $4 \%$ milk powder and $8 \%$ pulps constituting Blend 1 (whey + milk + açaí), Blend 2 (whey + milk + cupuaçu) and Blend 3 (whey + milk + soursop). Pasteurized milk, sugar and milk powder were added to the whey, mixed and subjected to pasteurization at $85{ }^{\circ} \mathrm{C}$ for 15 minutes. Then, the mixture was cooled in a water bath at temperature of $42{ }^{\circ} \mathrm{C}$, so that the yeast could be added as recommended by the manufacturer. Fermentation was carried out in BOD incubator at $42{ }^{\circ} \mathrm{C}$ for 5 hours, followed by cooling in refrigerator at $5{ }^{\circ} \mathrm{C}$ for 30 minutes, break of the curd and addition of the pulps.

\section{Physicalchemical analysis}

The dairy drinks were placed in $750-\mathrm{mL}$ plastic bottles previously sanitized and sterilized in water at $100{ }^{\circ} \mathrm{C}$ and stored under refrigeration at $10{ }^{\circ} \mathrm{C}$. After processing, all treatments that visually showed apparent viscosity were subjected to physicochemical analyses $\left(\mathrm{pH}\right.$, acidity, $\mathrm{L}, \mathrm{a}^{*}, \mathrm{~b}^{*}$ and -Brix).

Analyses of $\mathrm{pH}$ were performed according to the Analytical Standards of the Adolfo Lutz Institute, with $\mathrm{pH}$ values determined in a digital potentiometer, properly calibrated with buffer solutions of $\mathrm{pH} 7.0$ and 4.0, using the Del Lab microprocessor digital $\mathrm{pH}$ meter. Acidity was determined using the complete Dornic acidimeter, and the technique consists in transferring $50 \mathrm{~mL}$ of sample with a pipette to a beaker, adding 5 drops of the indicator (phenolphthalein) and titrating with Dornic solution $(0.11 \mathrm{~N} \mathrm{NaOH})$ until reaching a persistent pink color for approximately 30 seconds (Brasil, 2007). Color was determined using the colorimeter Minolta CR $400 \mathrm{CIE} \mathrm{L*a*b}$ model. The L* coordinate represents how light or dark the sample is, with values ranging from 0 (completely black) to 100 (completely white); the a* coordinate can assume values from -80 to +100 , where the extremes correspond to green and red, respectively; and the $b^{*}$ coordinate corresponds to the intensity from blue to yellow, which can range from -50 (completely blue) to +70 (completely yellow).

\section{Sensory analysis}

The sensory acceptance test (attributes of color, texture, consistency, aroma, flavor and overall aspect) was conducted at seven days of storage. Sensory acceptance was evaluated by untrained tasters ( 80 tasters), considering the scores according to the hedonic scale with values from 1 to 9 points (1- Disliked extremely, 2- Disliked very much, 3- Disliked moderately, 4- Disliked slightly, 5- Neither liked nor disliked, 6- Liked slightly, 7- Liked moderately, 8- Liked very much and 9- Liked extremely), indicating how much they liked or disliked the color, texture, aroma, flavor and overall aspect of the products. The samples were coded with three-digit numerals and randomized with numbers to be presented to the 80 evaluators, and the preference was obtained by average, considering the three flavors of milk drink (cupuaçu, soursop and açaí). Microbiological determinations were carried out using methodologies described by Brasil (2003), evaluating the presence of total and thermotolerant coliforms, Escherichia coli, Staphylococcus aureus, Salmonella sp., according to the microbiological parameters established by the legislation for fermented milk drinks (Brasil, 2005).

\section{Statistical analysis}

Physicochemical and sensory results were subjected to analysis of variance and the differences between means were compared by Tukey test at $5 \%$ significance level, using the statistical program Sisvar.

\section{Conclusions}

Whey concentration of $50 \%$ with addition of cupuaçu, soursop and açaí pulps is ideal for the production of fermented milk drink, as it leads to increased acidity and 
reduced values of ${ }^{\circ}$ Brix and color parameters $L$ and $b^{*}$, making it possible to avoid the disposal of a highly nutritious compound into the environment.

Whey concentration of $30 \%$ in the presence of açaí pulp enables the processing of milk drink with lower value of acidity and higher values of ${ }^{\circ}$ Brix and color parameters $L$ and b*.

Whey concentrations of $30 \%$ and $40 \%$ in the fermented milk drink of cupuaçu, soursop and açaí reduced acidity and increased ${ }^{\circ} \mathrm{Brix}$, which suggests the possibility of utilizing this by-product in the food industry to prepare sweeter milk drinks, meeting the minimum quality requirements according to the current legislation.

The processing of whey-based dairy beverage in the presence of pulps of fruits, such as cupuaçu, soursop and açaí, constitutes an opportunity for diversification of production, improvement in the development of regional products and guarantee of food and nutritional security, respecting microbiological quality standards.

\section{Acknowledgments}

The authors thank the Federal Institute of Rondonia and the Department of Research, Innovation and Graduate Studies for providing resources and scientific initiation scholarships.

\section{References}

Andrade RLP, Martins JFP (2002 Influence of the addition of sweet potato starch (Ipomoea batatas L.) on the viscosity of the cheese serum permeate. Food Sci Tech. 22: 249-253.

Antunes AJ (2003) Functionality of bovine whey proteins, 1a ed., Editora Manole Ltda.

Barbosa AS, Florentino IR, Florêncio IM, Araújo AS (2010) Use of serum as substrate for brandy production: kinetic study of ethanol production. Green Magazine. 5 (1): 7-25.

Baskar R, Rajeswari V, Sathish T (2007) In vitro antioxidant studies in leaves of Annona species. Indian J Exp Biol. 45(5): 480-485.

Brazil (2003) Ministry of Agriculture, Livestock and Supply. Department of Animal Product Inspection. Normative Instruction No. 62 of August 26, 2003. Officializes the official analytical methods for microbiological analysis for control of animal products and water. Official Gazette [of] Federative Republic of Brazil. Brasília, DF, 18 de setembro de 2003. Seção 1, p.14.

Brazil (2005) Ministry of Agriculture, Livestock and Supply. Department of Animal Product Inspection. Normative Instruction No. 16 of August 23, 2005. Approves the Technical Regulation of Identity and Quality of Dairy Beverages. Official Gazette [of] Federative Republic of Brazil. Brasília, DF, 24 de agosto de 2005. Seção 1, p.7.

Brazil (2007). Ministry of Agriculture, Livestock and Supply. Department of Animal Product Inspection. Normative Instruction No. 46 of October 23, 2007. It adopts the Technical Regulation of Identity and Quality of Fermented Milks. Official Gazette [of] the Federative Republic of Brazil. Brasília, DF, 24 de outubro de 2007. Seção 1, p. 5.

Capitani CD, Pacheco MTB, Gumerato HF, Vitali A, Schimidt FL (2005) Recovery of whey proteins by polysaccharide conservation. Pesq Agropec Braz. 40:1123-1128.

García-Pérez FJ, Lario Y, Fernández-López J, Sayas E, PérezAlvarez JÁ, Sendra E (2005) Effect of orange fiber addition on yogurt color during fermentation and cold storage. Industrial Apllications. 30(6): 457-463.
Guedes AFLM, Machado ECL, Fonseca MC, Andrade SAC, Stamford TLM (2013) Use of dairy serum in the formulation of beverages with fruits and vegetables. Arq. Braz. Med. Vet. Zootec. 65(4):1231-1238.

Brazilian institute of geography and statistics (IBGE). Livestock Production Statistics Oct.-Dec. 2019. Rio de Janeiro, p.1-81, $2020 . \quad$ Available in: https://biblioteca.ibge.gov.br/visualizacao/periodicos/238 0/epp_2019_4tri.pdf

Kandler O, Weiss N (1986) Regular, nonsporing Gram-positive rods. In: Krieg NR, Holt JG (Eds.). Bergey`s Manual of determinative bacteriology. 9 ed. Baltimore, The Williams and Wilkins Co. p.1208-1234.

Leite MT, Barrozo M, Ribeiro J (2012) Canonical analysis technique as an approach to determine optimal conditions for lactic acid production by Lactobacillus helveticus ATCC 15009. Inter. J. of Chem. Eng. 13(1):1-9.

Macêdo WVL, Abreu LP, Sisnando IMP, Silva JN (2011) Physical-chemical evaluation of fermented milk drink passion fruit flavor (Passiflora edulis). In: 3rd UFC University Meeting at Cariri. Juazeiro do Norte-CE. 1 CD.

Menezes ACS (2011) Development of fermented milk drink based on whey and cajá pulp (Spondias Mombin L.) with potential probiotic activity. 2011. 106f. Thesis (Master's degree in Food Science and Technology) Federal Rural University of Pernambuco, Recife.

Paula NRF, Araújo EO, Almeida EE, Cerqueira JP (2020) Development and Physicochemical, Sensory and Microbiological Characterization of Ferment Milk With Addition of Cupuaçu. J. of Agric. Scie. 12(5): 122-130.

Paula NRF, Araújo EO, Almeida EE, Rezende ASS (2020) Physicochemical and Sensory Quality of Fermented Milk With Different Blends of Theobroma grandiflorum and Theobroma cacao. J. of Agric. Scie. 12(5): 131-138.

Pintado ME (2001) Review: technology, chemistry and microbiology of whey cheeses. Food Sci. Technol. Int. 7: 105-116.

Santos CT, Marques GMR, Fontan G, Fontan RCI (2006) Elaboration and characterization of a fermented milk drink with umbu pulp (Spondias tuberosa sp.). Braz. Jour. of Agroind. Prod.. 8(2): 111- 116.

Santos JPV, Ferreira CLL (2001) Alternatives for the use of cheese serum in small and medium-sized dairy products. Rev. Inst. Lat. Candido Tostes. 56: 44-50.

Siqueira AO, Machado ECL, Stamford TLM (2013) Dairy drinks with cheese serum and fruit. Rural Science, Santa Maria. 43(9): 1693-1700.

Siqueira IMC, Souza MR, Cerqueira MMOP (2002) Importance and use of cheese serum derivatives. Hig. I'm sorry. 16: 3135. 